Avoimesti luettavissa osoitteessa http://journal.fi/ainedidaktiikka

\title{
ainedidaktiikka
}

\section{Ainedidaktiikan yhteinen kehittäminen}

Toimittajina olemme iloksemme huomanneet, että nyt ilmestyvälle ainedidaktiikan alan suomenkieliselle julkaisulle on selkeä tarve. Lehteen on tarjottu runsaasti artikkeleita ja lehden toimituskuntaan on lupautunut didaktiikan aloittain ja maantieteellisesti kattava ryhmä asiantuntijoita. Toimituskunnan rooli on merkittävä, kun artikkeleille valitaan asiantuntija-arvioitsijoita. Lehden tietokantaan on ilmoittautunut vertaisarvioijaksi lähes 50 ainedidaktiikan alan tutkijaa. Kohteliaimmin kiitämme kaikkia lehden käynnistysvaiheessa mukaan tulleita ja toivotamme edelleen tervetulleeksi mukaan uusia ainedidaktiikasta kiinnostuneita.

Koska tavoitteenamme on korkeatasoinen suomalainen tieteellinen julkaisu, noudatamme alusta asti tieteellisten seurain valtuuskunnan ohjeiden mukaista arviointikäytäntöä. Ainedidaktiikka on Suomen ainedidaktisen tutkimusseuran lehti. Olemme sitoutuneet open access julkaisemiseen. Lehti ei siis peri lukija- tai kirjoittajamaksuja. Seuran kirjasarja saa käyttää Tieteellisten seurain valtuuskunnan vertaisarviointitunnusta ja sarja on luokiteltu Julkaisufoorumiluokittelussa tasolle 1. Pyrimme saamaan samat muodolliset tunnustukset myös Ainedidaktiikka-lehdelle mahdollisimman pian. Käynnistyvällä julkaisusarjalla tulee vastaan lukuisia käytänteisiin liittyviä seikkoja, jotka edellyttävät harkintaa ja uudelleen ajattelua. Siten ensimmäiset numerot eivät ole edenneet aivan niin nopeasti kuin alussa toivoimme. Tästä esitämme pahoittelut kirjoittajille ja kiitämme kaikkia artikkeleita tarjonneita ja arvioineita henkilöitä pitkämielisyydestä.

Lehden ensimmäisessä numerossa on kolme vertaisarvioitua artikkelia. Kirjoittajat tarkastelevat ympäristökasvatusta, kahdeksasluokkalaisten näkemyksiä islaminopetuksesta ja perusopetuksen oppilaiden asennoitumista käsityöoppiaineeseen. Suomessa, kuten muissakin maissa, julkaistaan runsaasti opettamista ja oppimista käsittelevää kirjallisuutta. Siksi toivotamme tervetulleeksi myös ainedidaktiikan tutkijoiden avaamia näkökulmia ja esittämiä arvosteluja uusista kasvatuksen alan kotimaisista ja kansainvälisistä kirjoista.

\section{Kalle Juuti, Seija Kairavuori ja Arto Kallioniemi}

Helsingin yliopisto, Kasvatustieteellinen tiedekunta 